\title{
Analisis Pemahaman Konsep Siswa Kelas VII Berdasarkan Taksonomi Bloom Ditinjau dari Kemampuan Kognitif
}

\author{
Restu Lusiana, Ika Krisdiana, Siti Aisyah
}

(C) 2018 JEMS (Jurnal Edukasi Matematika dan Sains)

This is an open access article under the CC-BY-SA license (https://creativecommons.org/licenses/bysa/4.0/) ISSN 2337-9049 (print), ISSN 2502-4671 (online)

\begin{abstract}
Abstrak: Penelitian ini bertujuan untuk mendeskripsikan pemahaman konsep berdasarkan taksonomi bloom dalam memecahkan masalah aljabar ditinjau dari kemampuan kognitif. Metode penelitian yang digunakan adalah pendekatan kualitatif. Subyek penelitian ini adalah siswa kelas VIII SMPN 2 Wungu. Teknik analisis data menggunakan reduksi data, penyajian data, dan penarikan kesimpulan. Hasil penelitian menunjukkan bahwa (1) Subjek dengan kemampuan kognitif tinggi dapat memenuhi semua tahapan pemecahan masalah dan memenuhi semua indikator pemahaman konsep berdasarkan taksonomi bloom. (2) Subjek dengan kemampuan kognitif sedang hanya memenuhi beberapa tahapan pemecahan masalah yang meliputi memahami masalah, merencanakan pemecahan masalah, dan menyelesaikan pemecahan masalah, serta memenuhi beberapa indikator pemahaman konsep yaitu pengetahuan, pemahaman, penerapan, dan analisis. (3) Subjek dengan kemampuan kognitif rendah hanya memenuhi tahapan penyelesaian masalah memahami masalah dan merencanakan pemecahan masalah, serta memenuhi beberapa indikator pemahaman konsep yaitu pengetahuan, pemahaman, dan penerapan.
\end{abstract}

Kata Kunci: Pemahaman Konsep; Taksonomi Bloom; Pemecahan Masalah; Aljabar; Kemampuan Kognitif

\begin{abstract}
This study aims to describe the understanding of concepts based on bloom's taxonomy in solving algebra problems in terms of cognitive abilities. The research method used is a qualitative approach. The subjects of this study were eighth grade students of SMPN 2 Wungu. Data analysis techniques using data reduction, data presentation, and drawing conclusions. The results showed that (1) Subjects with high cognitive abilities can meet all stages of problem solving and meet all indicators of understanding concepts based on bloom taxonomy. (2) Subjects with cognitive abilities are only fulfilling several stages of problem solving which include understanding the problem, planning problem solving, and solving problem solving, as well as fulfilling several indicators of concept understanding namely knowledge, understanding, application, and analysis. (3) Subjects with low cognitive abilities only meet the stages of problem solving, understanding problems and planning problem solving, as well as meeting several indicators of concept understanding, namely knowledge, understanding, and application.
\end{abstract}

Keywords: Concept Understanding; Bloom's Taxonomy; Problem Solving; Algebra; Cognitive Ability

\section{Pendahuluan}

Pemahaman konsep dalam matematika merupakan salah satu langkah utama siswa dalam menerima dan memahami materi-materi selanjutnya (Fitrah, 2017). Konsep dalam matematika diungkapkan dalam bentuk definisi (Bahar, Rahman, \& Minggi, 2012). Pada kenya-

Restu Lusiana, Universitas PGRI Madiun

restu.mathedu@unipma.ac.id

Ika Krisdiana, Universitas PGRI Madiun

ika.mathedu@unipma.ac.id

Siti Aisyah, Universitas PGRI Madiun

sitiaisyah@gmail.com 
taannya penguasaan konsep matematika siswa sekolah menengah masih lemah, mereka kurang memiliki kemampuan pemahaman yang baik terhadap konsep dasar matematika (Rohaeti, 2012) (Yunita, 2014). Permasalahan tersebut juga dialami oleh siswa SMPN 2 Wungu kelas VIII, hal itu dibuktikan dengan: (1) siswa sulit menjelaskan kembali materi pertemuan sebelumnya, (2) jika guru memberikan soal yang sedikit berbeda dengan contoh, siswa sukar mengerjakan soal tersebut, (3) sebagian besar siswa tidak bisa menafsirkan suatu masalah bahasan matematika ketika mengerjakan soal latihan. Berdasarkan realita tersebut dapat dikatakan bahwa tujuan dari belajar atau proses pembelajaran matematika belum tercapai dengan baik.

Tujuan pembelajaran dapat tercapai dengan berbagai upaya yang dilakukan oleh guru, salah satunya adalah dengan Taksonomi Bloom (Juhanda, 2014) (Gunawan \& Palupi, 2017). Taksonomi Bloom yang baru terdiri dari dua dimensi yaitu dimensi proses kognitif dan dimensi pengetahuan (Ardiani, Guna, \& Novitasari, 2013). Dalam dimensi tersebut diantaranya terdapat proses memahami, menerapkan, menganalisa, dan mengevaluasi yang merupakan tahapan dalam pemahaman konsep.

Berdasarkan hasil observasi yang dilakukan peneliti di SMPN 2 Wungu kesulitan siswa dalam pembelajaran matematika terletak pada pemahaman konsep dalam memecahkan masalah aljabar. Sebagian besar siswa menganggap bahwa konsep aljabar merupakan konsep yang rumit. Hal tersebut berdampak pada kurangnya kemampuan siswa dalam memecahkan permasalahan aljabar, diantaranya dalam hal: mengidentifikasi informasi yang diketahui dan yang ditanyakan, memanipulasi aljabar, melakukan operasi aljabar, membuat kesimpulan, serta memperbaiki kesalahan yang dilakukan (Haryati, Suyitno, \& Junaedi, 2015). Pemecahan mempunyai interpretasi yang berbeda, misalnya menyelesaikan soal cerita yang tidak rutin dan meng- aplikasikan matematika dalam kehidupan sehari-hari (Ristiana, Rati, \& Yuanita, 2015).

Banyak penelitian yang melihat proses penyelesaian masalah matematika siswa berdasarkan beberapa hal, diantaranya gender (Fuad, 2016), kemampuan matematika (Andhani, 2016), gaya kognitif (Santia, 2015), dan lain-lain. Penelitian ini akan melihat pemahaman konsep siswa dalam menyelesaikan masalah berdasarkan kemampuan kognitif. Kemampuan kognitif berhubungan dengan persepsi, pemikiran, ingatan, keterampilan, pengolahan informasi yang memungkinkan seseorang memperoleh pengetahuan untuk dapat memecahkan masalah (Hidayat \& Maulidiyah, 2017). Kemampuan kognitif masing-masing individu pastilah berbeda, kemampuan siswa dalam memahami konsep matematikapun juga beraneka ragam (Rosa, 2017), sehingga pada penelitian ini akan dianalisis pemahaman konsep siswa dalam menyelesaikan masalah aljabar ditinjau dari kemampuan kognitif.

\section{Metode}

Penelitian yang digunakan dalam penelitian ini adalah penelitian deskriptif dengan pendekatan kualitatif. Arifin (2012) mengemukakan bahwa penelitian kualitatif adalah suatu proses penelitian yang dilakukan secara wajar dan natural sesuai dengan kondisi objektif di lapangan tanpa adanya manipulasi.

Subjek pada penelitian ini adalah 3 siswa kelas VIII C SMP Negeri 2 Wungu dengan kemampuan kognitif tingkat tinggi, sedang, dan rendah. Kategori kemampuan kognitif tinggi, sedang, dan rendah ditentukan dengan menggunakan penelitian acuan patokan (PAP) (Budiyono, 2009) sebagai berikut: 
Tabel 1. Penentuan Kategori Subyek

\begin{tabular}{cc}
\hline Skor & Kategori \\
\hline $70<$ skor $\leq 100$ & Tinggi \\
\hline $30<$ skor $\leq 70$ & Sedang \\
\hline $0<$ skor $\leq 30$ & Rendah \\
\hline
\end{tabular}

Dalam penelitian kualitatif instrumennya adalah peneliti sendiri, namun selanjutnya setelah fokus penelitian sudah jelas, maka dikembangkan instrumen penelitian sederhana, yang diharapkan dapat melengkapi data dan membandingkan dengan data yang telah ditemukan melalui observasi, tes, dan wawancara (Sugiyono, 2008).

Teknik pengumpulan data yang digunakan yaitu observasi, wawancara, dan dokumentasi. Adapun Teknik pengujian keabsahan data menggunakan triagulasi waktu, yaitu dilakukan dengan cara membandingkan data yang diperoleh dari hasil tes dan wawancara pada waktu yang berbeda terhadap subyek yang sama sampai mendapatkan data jenuh. Sedangkan analisis data yang digunakan yaitu reduksi data (data reduction), penyajian data (data display), dan penarikan kesimpulan (conclusion drawing? verifying).

\section{Hasil dan Pembahasan}

\section{Hasil}

Dari hasil tes kemampuan kognitif diambil 3 subjek yang terdiri dari siswa dengan kemampuan kognitif tinggi, sedang, dan rendah. Setelah itu siswa diberikan permasalahan aljabar untuk melihat pemahaman konsep yang dimiliki oleh masing-masing subjek. Adapun permasalahan yang diberikan kepada subjek adalah "Seorang tukang parkir mendapatkan uang sebesar Rp 17.000,00 dari 3 mobil dan 5 motor, sedangkan dari 4 mobil dan 2 motor ia mendapatkan uang sebesar Rp 18.000,00. Tentukan hasil uang parkir yang ia peroleh jika terdapat 20 mobil dan 30 motor!"

Dibawah ini merupakan hasil analisis data pemahaman konsep dalam menyelesaikan masalah dari masing-masing subjek.

a. Analisis Data Tes Tulis dan Wawancara Subyek Kemampuan Kognitif Tinggi

Tabel 2. Analisis Data Tes dan Wawancara Subjek Kemampuan Kognitif Tinggi

\begin{tabular}{|c|c|c|}
\hline Tahap & Tes Tulis & Wawancara \\
\hline \multirow[t]{10}{*}{ Memahami Masalah } & - Subjek mampu memahami & - Subjek mampu memahami \\
\hline & masalah mampu menerjemahkan & masalah dengan menerjemahkan \\
\hline & dan mengidentifikasi & informasi terpenting dalam \\
\hline & $\begin{array}{l}\text { terpenting dalam permasalahan } \\
\text { yang ada pada soal. }\end{array}$ & $\begin{array}{l}\text { permasalahan yang ada pada } \\
\text { soal. }\end{array}$ \\
\hline & - Subjek menuliskan apa yang & - Subjek menjelaskan dan \\
\hline & $\begin{array}{l}\text { diketahui dan ditanyakan dari soal } \\
\text { pada lembar jawaban. }\end{array}$ & $\begin{array}{l}\text { menuliskan apa yang diketahui } \\
\text { dan ditanyakan dari soal pada }\end{array}$ \\
\hline & Diket: & lembar jawaban. \\
\hline & -3 mobil dan 5 motor : Rp.17.000,00 & \\
\hline & -4 mobil dan 2 motor : $R p \cdot 18 \cdot 000,00$ & \\
\hline & Ditanya: hasil uang parkir 20 mobil dan 30 motor? & \\
\hline $\begin{array}{l}\text { Merencanakan } \\
\text { Pemecahan Masalah }\end{array}$ & $\begin{array}{l}\text { - Subjek mampu merencanakan } \\
\text { pemecahan masalah dengan cara }\end{array}$ & $\begin{array}{l}\text { - Subjek mampu merencanakan } \\
\text { pemecahan masalah dengan }\end{array}$ \\
\hline
\end{tabular}




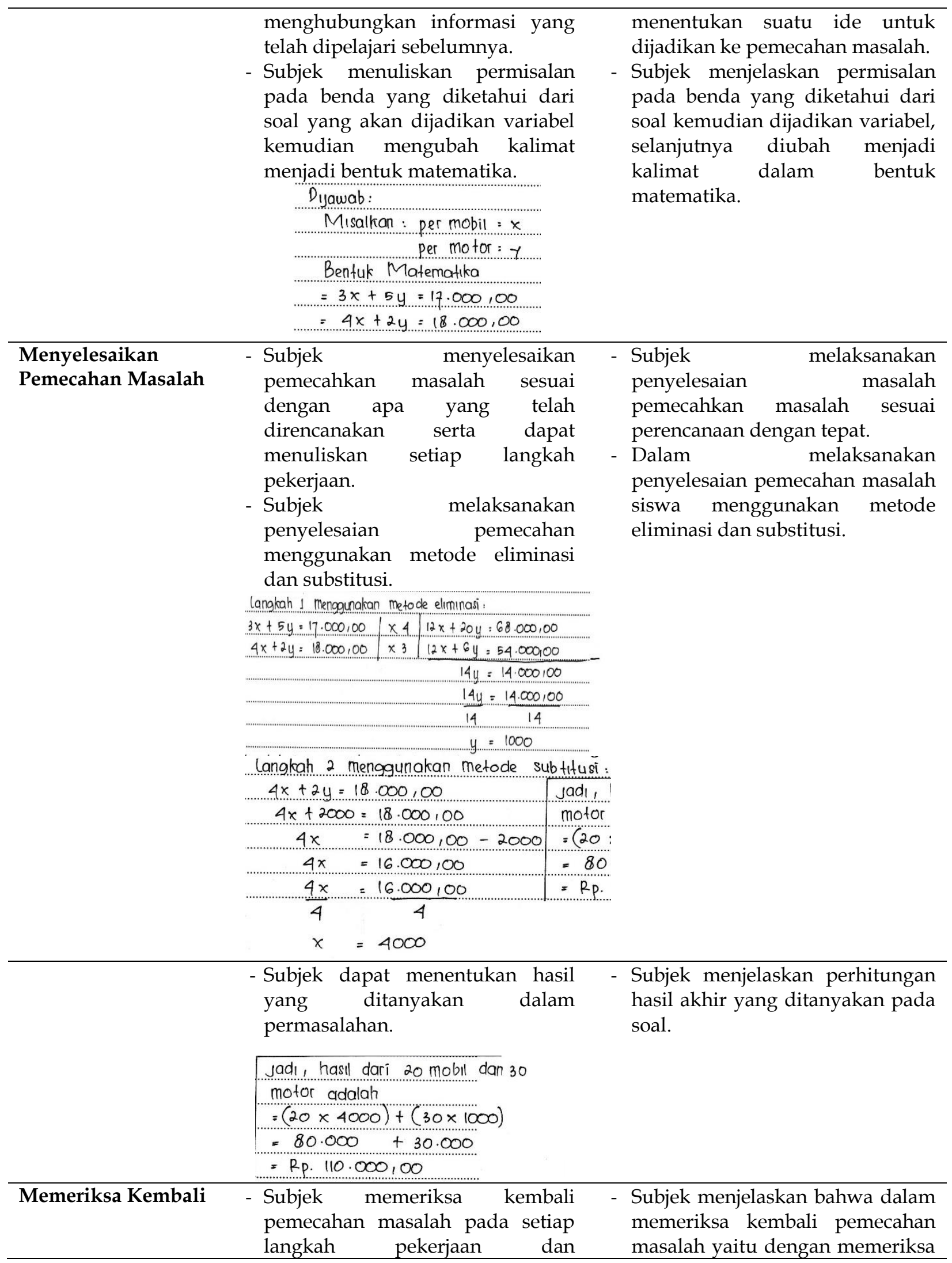




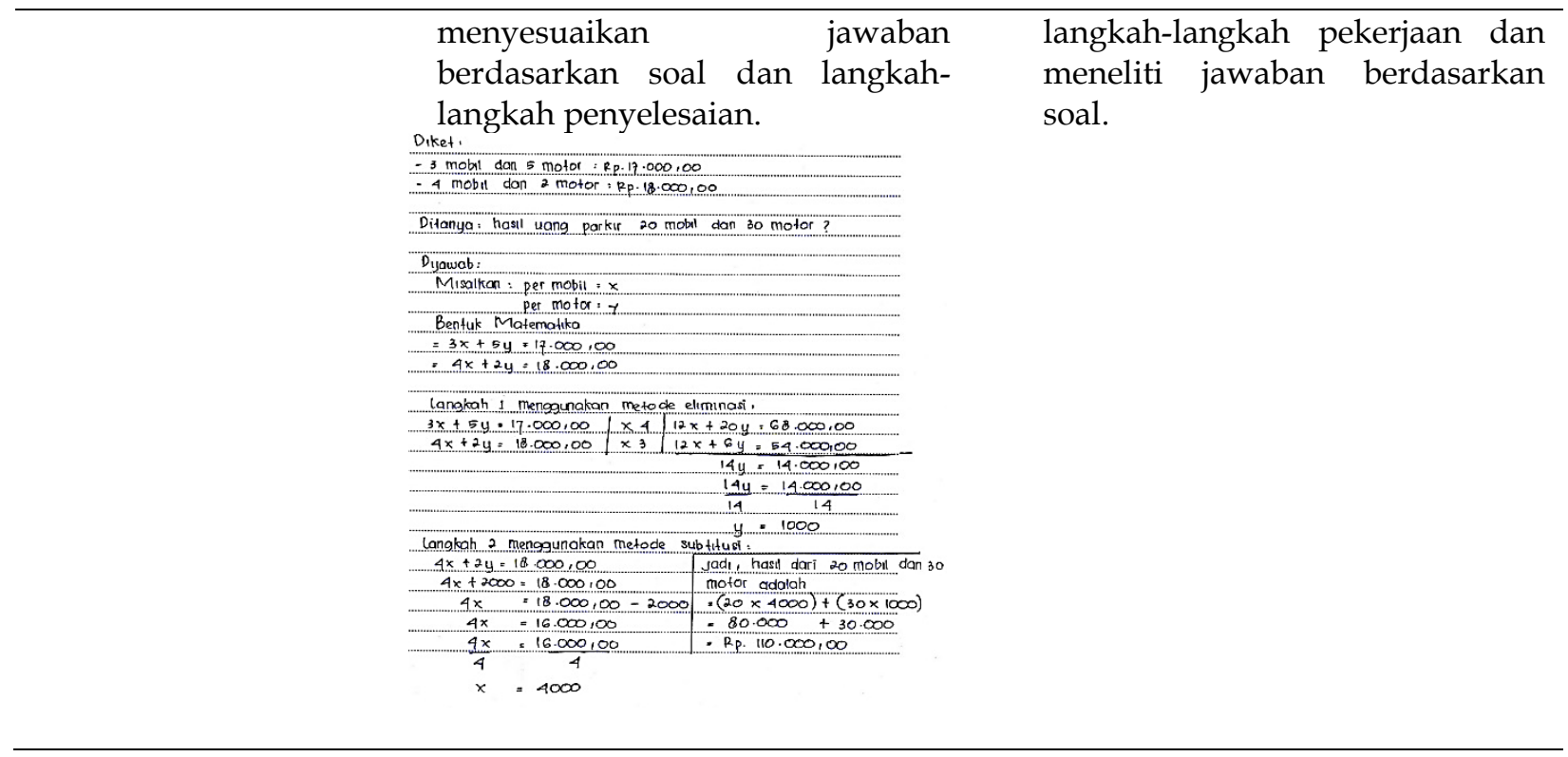

b. Analisis Data Tes Tulis dan Wawancara Subyek Kemampuan Kognitif Sedang

Tabel 4.2 Validasi Data Subyek 2 (Kemampuan Kognitif Sedang)

\begin{tabular}{|c|c|c|}
\hline Tahap & Tes Tulis & Wawancara \\
\hline Memahami Masalah & 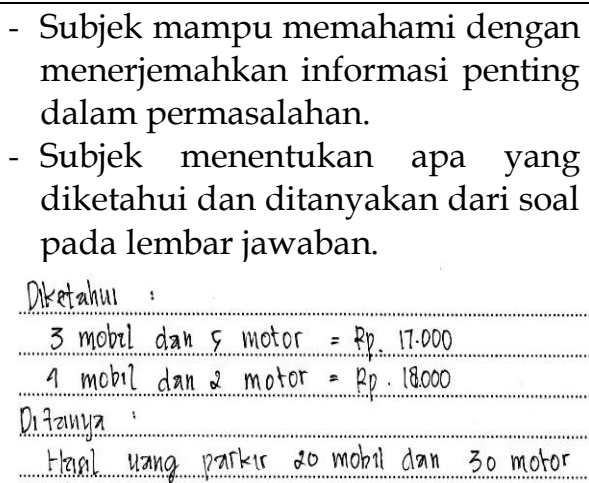 & $\begin{array}{l}\text { - Subjek memahami masalah } \\
\text { dengan mengambil inti-inti pada } \\
\text { soal. } \\
\text { - Subjek mengungkapkan apa yang } \\
\text { diketahui dan ditanyakan dalam } \\
\text { permasalahan. }\end{array}$ \\
\hline $\begin{array}{l}\text { Merencanakan } \\
\text { Pemecahan Masalah }\end{array}$ & 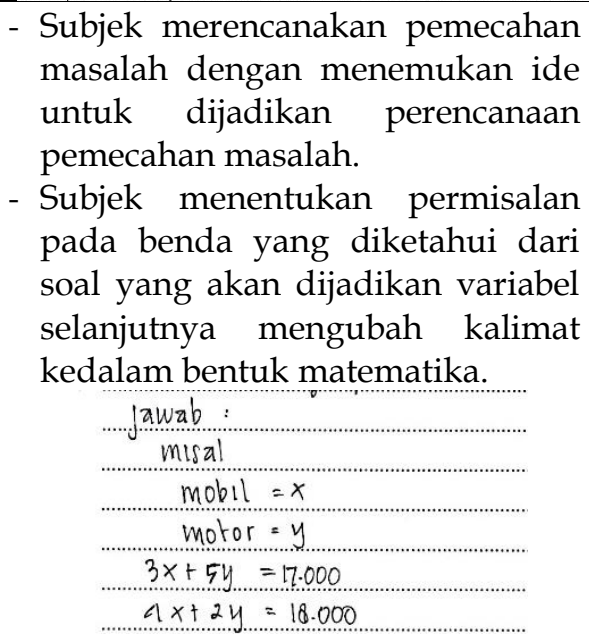 & $\begin{array}{l}\text { - } \text { Subjek dapat merencanakan } \\
\text { pemecahan masalah dengan } \\
\text { setelah memahami masalah yang } \\
\text { ada pada soal. } \\
\text { - Subjek menjelaskan permisalan } \\
\text { berupa variabel kemudian } \\
\text { membuat kalimat dalam bentuk } \\
\text { matematika. }\end{array}$ \\
\hline Menyelesaikan & - Subjek belum dapat menuntaskan & - Subjek \\
\hline
\end{tabular}




\begin{tabular}{|c|c|c|}
\hline Pemecahan Masalah & $\begin{array}{l}\text { proses pemecahkan masalah. } \\
\text { - Dalam melaksanakan } \\
\text { penyelesaian pemecahan masalah } \\
\text { untuk mencari nilai } y \text {. }\end{array}$ & $\begin{array}{l}\text { menyelesaikan pemecahkan } \\
\text { masalah. } \\
\text { - Subjek melakukan penyelesaian } \\
\text { masalah untuk mencari nilai } y\end{array}$ \\
\hline & 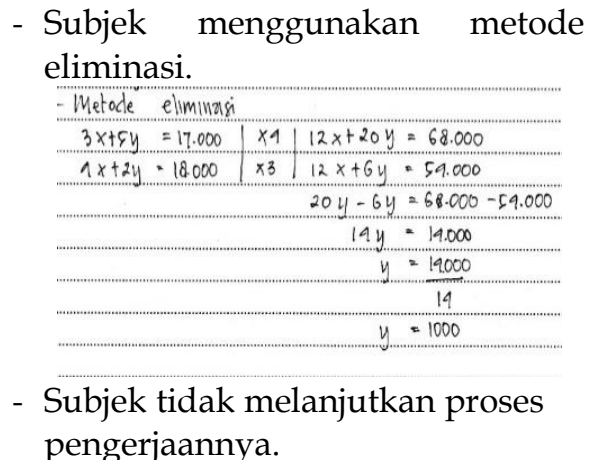 & $\begin{array}{l}\text { - Subjek menggunakan metode } \\
\text { eliminasi. } \\
\text { - Subjek tidak menyelesaikan } \\
\text { pemecahan masalah dikarenakan } \\
\text { lupa cara mengerjakannya. }\end{array}$ \\
\hline Memeriksa Kembali & $\begin{array}{l}\text { - Karena tidak dapat melakukan } \\
\text { proses pengerjaan yang baik, } \\
\text { subjek tidak memeriksa kembali } \\
\text { pekerjaannya. }\end{array}$ & $\begin{array}{l}\text { - Subjek tidak dapat melakukan } \\
\text { memeriksa kembali hasil } \\
\text { jawabannya, dikarenakan tidak } \\
\text { menyelesaikan proses pemecahan } \\
\text { masalah. }\end{array}$ \\
\hline
\end{tabular}

c. Analisis Data Tes Tulis dan Wawancara Subyek Kemampuan Kognitif Rendah

Tabel 3. Validasi Data Subyek 3 (Kemampuan Kognitif Rendah)

\begin{tabular}{|c|c|c|}
\hline Tahap & Tes Tulis & Wawancara \\
\hline Memahami Masalah & 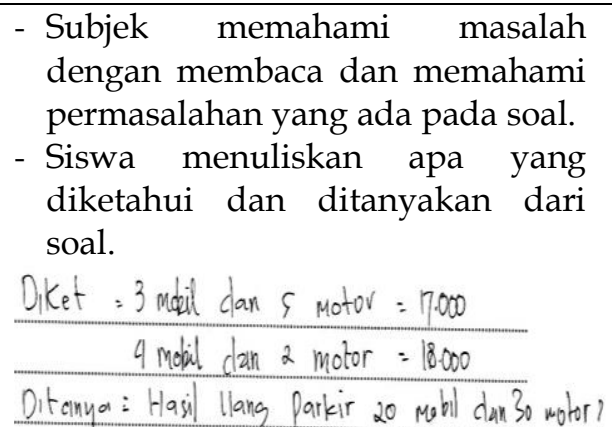 & $\begin{array}{l}\text { - Subjek mampu memahami } \\
\text { masalah dengan cara membaca } \\
\text { untuk menemukan informasi } \\
\text { penting dari permasalahan. } \\
\text { - Subjek dapat menjelaskan } \\
\text { informasi apa yang diketahui dan } \\
\text { ditanyakan. }\end{array}$ \\
\hline $\begin{array}{l}\text { Merencanakan } \\
\text { Pemecahan Masalah }\end{array}$ & $\begin{array}{l}\text { - Subjek mampu merencanakan } \\
\text { pemecahan masalah dengan } \\
\text { memperoleh solusi untuk } \\
\text { mengerjakan langkah pemecahan } \\
\text { masalah. } \\
\text { - Subjek menuliskan permisalan } \\
\text { pada benda yang diketahui dari }\end{array}$ & $\begin{array}{l}\text { - Subjek dapat mengungkapkan ide } \\
\text { dari permasalahan untuk dijadikan } \\
\text { perencanaan pemecahan masalah. } \\
\text { - Subjek membuat permisalan } \\
\text { berupa variabel kemudian } \\
\text { mengubah kalimat kedalam bentuk } \\
\text { matematika. }\end{array}$ \\
\hline
\end{tabular}
soal yang akan dijadikan variabel kemudian mengubah kalimat kedalam bentuk matematika. 


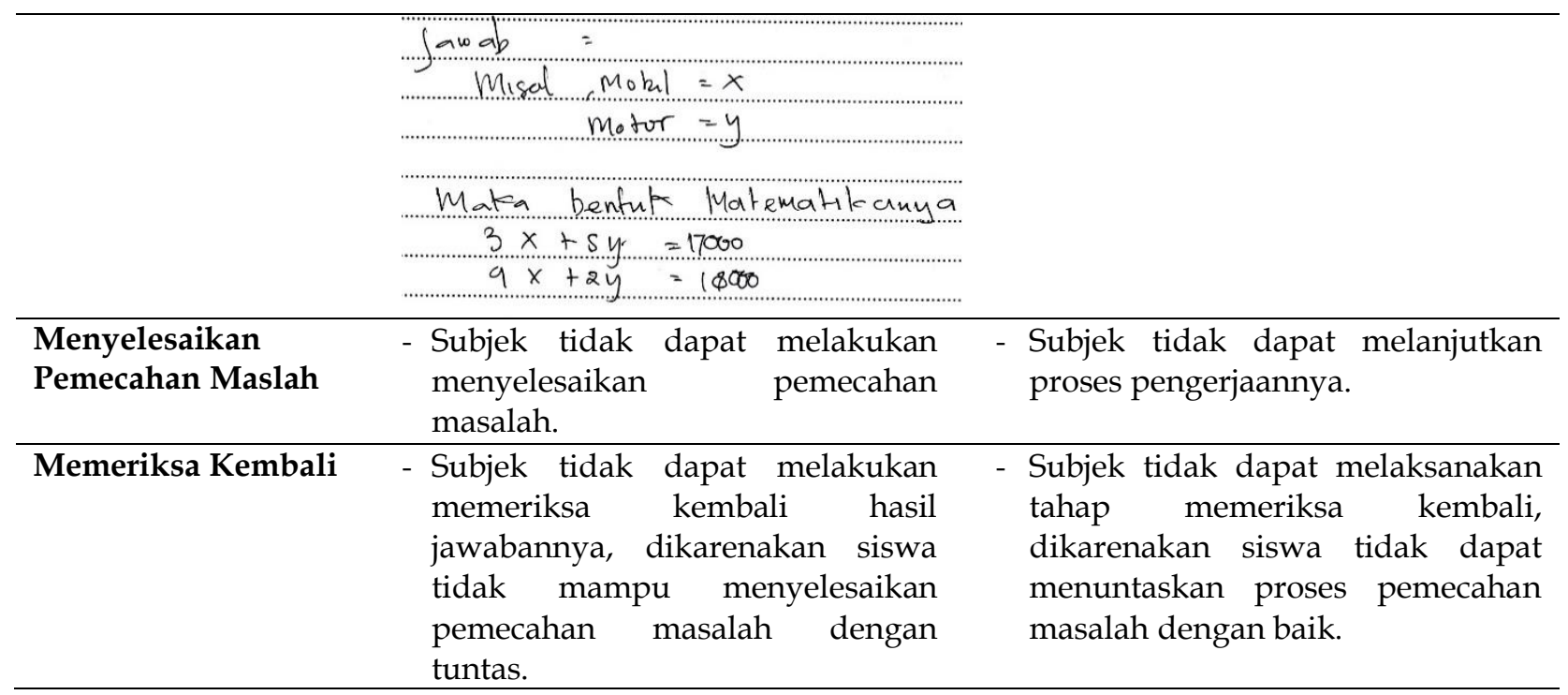

\section{Pembahasan}

a. Subjek dengan Kemampuan Kognitif Tinggi

Berdasarkan analisis data diatas didapatkan hasil bahwa subjek dengan kemampuan kognitif tinggi mengenal informasi dalam permasalahan dan dapat merubahnya ke dalam bentuk matematika. Subjek juga dapat menyebutkan permasalahan dengan lengkap dan benar saat wawancara. Subjek memahami masalah berdasarkan indikator pengetahuan dan pemahaman yang terlihat pada bagaimana siswa mampu menerjemahkan dan mengidentifikasi bagian terpenting dalam permasalahan dengan menuliskan apa yang diketahui dan ditanyakan dengan benar, sehingga muncul penafsiran dalam memecahkan masalah.

Subjek merencanakan pemecahan masalah berdasarkan indikator penerapan, yaitu menerapkan teori atau konsep dengan menentukan permisalan berupa variabel dan membuat kalimat dalam bentuk matematika dengan tepat. Hal ini juga dijelaskan ketika wawancara yaitu menentukan permisalan berupa variabel $x$ dan $y$ untuk benda yang diketahui, kemudian mengubah kalimat kedalam bentuk matematika. Berdasarkan hasil tes tulis dan hasil wawancara, subjek merencanakan pemecahan masalah dengan penerapan, yang berarti subjek dapat menggunakan konsep atau metode untuk menggambarkan perencanaan pemecahkan masalah yang ada pada soal.

Dalam menyelesaikan pemecahan masalah, subjek memenuhi indikator analisis dan sintesis, yaitu mengidentifikasi unsur dari suatu konsep kemudian mengembangkan prosedur atau perencanaan dari suatu konsep dengan menuliskan persamaan menggunakan kalimat bentuk matematika, kemudian dengan lancar melakukan operasi hitung menggunakan metode penyelesaian eliminasi dan substitusi, kemudian menghitung dan menentukan hasil akhir dari apa yang ditanyakan pada permasalahan dengan rinci dan tepat. Siswa menuliskan langkah pertama menggunakan metode eliminasi untuk menentukan nilai $y$, sedangkan untuk menentukan nilai $x$ siswa menggunakan metode penyelesaian substitusi. Saat wawancara subjek juga dapat menjawab dengan lancar tentang proses penyelesaian masalah yang dilakukannya.

Subjek menjelaskan bahwa dalam memeriksa kembali setiap langkah pengerjaan dengan meneliti jawaban berdasarkan soal dan langkah penyelesaian. Hal ini tergambar dari cara penulisan langkah penyelesaian yang terstruktur sehingga memudahkan untuk memeriksa 
kembali penyelesaian masalahnya. Dalam memeriksa kembali siswa memenuhi indicator evaluasi, yang berarti mampu menguji kebenaran atau menghitung kembali hasil pemecahan masalah dari soal yang diberikan.

b. Subjek dengan Kemampuan Matematika Sedang

Subjek memahami masalah yang telah dibaca dari soal cerita dengan mengambil inti-inti dari soal tersebut sehingga memenuhi indikator pengetahuan dan pemahaman, hal itu terlihat pada bagaimana siswa mampu menafsirkan dan mengidentifikasi informasi penting dalam permasalahan dengan menuliskan apa yang diketahui dan ditanyakan secara runtut

Subjek merencanakan pemecahan masalah berdasarkan indikator penerapan, yang berarti menerapkan teori atau konsep yang telah disusun dengan menentukan permisalan berupa variabel dan membuat persamaan kalimat dalam bentuk matematika dengann benar dan tepat. Subjek menentukan permisalan berupa variabel $x$ dan $y$ untuk benda yang diketahui, kemudian membuat kalimat kedalam bentuk matematika. Subjek dapat menghubungkan apa yang diketahui dalam masalah dan menentukan ide dengan baik dan benar.

Pada tahap menyelesaikan permasalahan, subjek kurang mampu menyelelesaikan masalah berdasarkan rencana pemecahan masalah yang sebelunya. Sehingga siswa tidak dapat menuntaskan pemecahkan masalah sesuai dengan apa yang telah direncanakan. Subjek menuliskan persamaan menggunakan kalimat bentuk matematika, kemudian siswa hanya menentukan nilai y dengan operasi hitung menggunakan metode penyelesaian eliminasi. Sedangkan untuk nilai $x$ dan hasil akhir dari permasalahan belum ditentukan oleh siswa. Pada saat wawancara, subjek mengungkapkan bahwa dia lupa cara mengerjakannya, sehingga menunjukkan bahwa siswa belum mampu menganalisis persamaan bentuk matematika kedalam metode penyelesaian dengan baik. Selain itu subjek juga mengungkapkan bahwa dia tidak melakukan proses memeriksa kembali hasil penyelesaian masalahnya.

c. Subjek dengan Kemampuan Matematika Rendah

Subjek dengan kemampuan kognitif rendah hanya mampu memenuhi dua tahapan pemecahan masalah dan tiga indikator pemecahan masalah. Subjek memahami masalah berdasarkan indikator pengetahuan dan pemahaman dengan menuliskan dan menjelaskan apa yang diketahui dan ditanyakan dalam permasalahan, sehingga subjek dapat dikatakan mengenal bentuk dan dapat mengartikan suatu kalimat satu permasalahan pada soal.

Siswa merencanakan pemecahan masalah memenuhi indikator penerapan, yaitu menerapkan suatu teori atau konsep yang dipahami sebelumnya dengan dengan membuat permisalan berupa variabel $x$ dan $y$. kemudian membuat persamaan menggunakan kalimat model matematika. Hal ini juga dijelaskan ketika wawancara yaitu menentukan permisalan berupa variabel $x$ dan $y$ untuk benda yang diketahui, kemudian mengubah kalimat kedalam bentuk matematika. Subjek mengenal bentuk persamaan linier dua variabel, sehingga subjek mampu menuliskan perencanaan penyelesaian masalahnya.

Pada tahap penyelesaian masalah, subjek ternyata tidak mampu dikarenakan lupa cara untuk mengerjakan dan menurutnya sulit untuk dikerjakan, sehingga tidak dapat melanjutkan rencana penyelesaian masalah yang telah ditulisnya. Subjek juga tidak dapat memeriksa kembali jawaban, dikarenakan tidak dapat menyelesaikan pekerjaannya sesuai langkahlangkah yang direncanakan sebelumnya.

\section{Simpulan}


1. Subjek dengan kemampuan kognitif tinggi dapat memenuhi semua tahapan pemecahan masalah dan memenuhi semua indikator pemahaman konsep berdasarkan taksonomi bloom.

2. Subjek dengan kemampuan kognitif sedang hanya memenuhi beberapa tahapan pemecahan masalah yang meliputi memahami masalah, merencanakan pemecahan masalah, dan menyelesaikan pemecahan masalah, serta memenuhi beberapa indikator pemahaman konsep yaitu pengetahuan, pemahaman, penerapan, dan analisis.

3. Subjek dengan kemampuan kognitif rendah hanya memenuhi tahapan penyelesaian masalah memahami masalah dan merencanakan pemecahan masalah, serta memenuhi beberapa indikator pemahaman konsep yaitu pengetahuan, pemahaman, dan penerapan.

\section{Daftar Rujukan}

Andhani, R. A. (2016). Representasi Eksternal Siswa dalam Pemecahan Masalah SPLDV Ditinjau dari Kemampuan Matematika. Kreano, Jurnal Matematika Kreatif-Inovatif, 7(2), 179186. https://doi.org/10.15294/kreano.v7i2.6615

Ardiani, N. F. W., Guna, N. A., \& Novitasari, R. (2013). Pembelajaran Tematik Dan Bermakna Dalam Perspektif Revisi Taksonomi Bloom. Satya Widya, 29(2), 93. https://doi.org/10.24246/j.sw.2013.v29.i2.p93-107

Bahar, E. E., Rahman, A., \& Minggi, I. (2012). Analisis Pemahaman Mahasiswa Terhadap Konsep Limit Fungsi di Satu Titik (Studi Kasus pada Mahasiswa Jurusan Matematika FMIPA UNM). Sainsmat, 1(2), 181-190.

Budiyono. (2009). Statistika untuk Penelitian. Surakarta: Sebelas Maret University Press.

Fitrah, M. (2017). Pembelajaran Berbasis Masalah Untuk Meningkatkan Pemahaman Konsep Matematika Pada Materi Segiempat Siswa Smp. KALAMATIKA Jurnal Pendidikan Matematika, 2(1), 51. https:/ / doi.org/10.22236/kalamatika.vol2no1.2017pp51-70

Fuad, M. N. (2016). Representasi Matematis Siswa SMA dalam Memecahkan Masalah Persamaan Kuadrat Ditinjau dari Perbedaan Gender. Kreano, Jurnal Matematika KreatifInovatif, 7(2), 145-152. https:// doi.org/10.15294/kreano.v7i2.5854

Gunawan, I., \& Palupi, A. R. (2017). Taksonomi Bloom-Revisi Ranah Kognitif Kerangka Landasan untuk Pembelajaran, Pengajaran, dan Penilaian. E-Journal.Unipma, 7(1), 1-8. Retrieved from http://e-journal.unipma.ac.id/index.php/PE

Haryati, T., Suyitno, A., \& Junaedi, I. (2015). Analisis Kesalahan Siswa Smp Kelas Vii Dalam Menyelesaikan Soal Cerita Pemecahan Masalah Berdasarkan Prosedur Newman. Unnes Journal of Mathematics Education., 5(1). https://doi.org/10.15294/ujme.v5i1.9341

Hidayat, \& Maulidiyah, E. C. (2017). Peningkatan Kemampuan Kognitif Anak Melalui Kegiatan Membilang Benda Sekitar. Jurnal Pendidikan Anak, 5(2).

Juhanda, I. A. (2014). Analisis Soal Jenjang Kognitif Taksonomi Bloom Revisi Pada Buku Sekolah Elektronika (BSE) Bilogi SMA. Pengajaran MIPA, 21(1), 61-66.

Ristiana, M., Rati, N., \& Yuanita, T. N. H. (2015). Strategi Pemecahan Masalah dalam 
Menyelesaikan Soal Certita pada Materi Persamaan dan Pertidaksamaan Linier Satu Variabel Siswa Kelas VII A SMP Kristen 02 salatiga. Satya Widya, 31(1), 8-16.

Rohaeti, E. E. (2012). Analisis Pembelajaran Konsep Esensial Matematika Sekolah Menengah Melalui Pendekatan Kontekstual Socrates. Infinity Journal, 1(2), 186. https://doi.org/10.22460/infinity.v1i2.18

Rosa, F. O. (2017). Eksplorasi Kemampuan Kognitif Siswa Terhadap Kemampuan Memprediksi, Mengobservasi, dan Menjelaskan Ditinjau dari Gender. Jurnal Pendidikan Fisika Universitas Muhammadiyah Metro, 5(2), 111-118.

Santia, I. (2015). Representasi Siswa Sma Dalam Memecahkan Masalah Matematika Berdasarkan Gaya Kognitif. JIPM (Jurnal Ilmiah Pendidikan Matematika), 3(2), 365-381. https://doi.org/10.25273/jipm.v3i2.505

Sugiyono. (2008). Metode Penelitian Kuantitatif, Kualitatif, dan RED. Bandung: Alfabeta.

Yunita, A. (2014). Pengaruh Metode Stratagem Melalui Pembelajaran Kooperatif Terhadap Pemahaman Konsep Matematis Siswa Kelas VIII SMP Negeri 20 Padang. Ta'dib, 17(1), 2536. 